\section{Cost-effectiveness analysis is a mandatory strategy for health systems: evidence from a study involving therapies for hepatitis C}

\author{
Análise de custo-efetividade é uma estratégia \\ essencial para os sistemas de saúde: \\ as evidências de um estudo sobre \\ terapias para hepatite $\mathrm{C}$
}
El análisis de coste-efectividad es una estrategia esencial para los sistemas de salud: evidencias de un estudio sobre terapias para hepatitis C

João Paulo Vilela Rodrigues 1,2 Maurílio de Souza Cazarim 1 Silvana Gama Florencio Chachá 3 Ana de Lourdes Candolo Martinelli 4 Leonardo Régis Leira Pereira 1

doi: 10.1590/0102-311X00036619

\begin{abstract}
Cost-effectiveness analysis is essential in health decision making. Several countries use it as synthesis of evidence to incorporate health technologies. The protease inhibitors (PI) boceprevir (BOC) and telaprevir (TVR) are indicated for chronic hepatitis $C$ treatment and were incorporated in guidelines worldwide. Pre-marketing clinical trials showed higher sustained virological response rates in relation to previous therapies, but the incorporation of PIs generated a significant financial impact. The aim of this study was to discuss the relevance of cost-effectiveness analysis through a study that involved the inclusion of PIs in a clinical protocol. The analysis was part of a real-life study that included patients infected with hepatitis $C$ virus genotype 1 treated in a tertiary university hospital in Brazil. Triple therapies (TT) with ribavirin $(R B V)$, peginterferon $\alpha-2 a(P e g-I N F \alpha-2 a)$ and BOC or TVR were compared to dual therapy with $R B V$ and Peg-INF $\alpha-2 a$. Sensitivity analysis of the costeffectiveness ratio indicated an $88.2 \%$ chance of TTs presenting a higher cost per cure. The incremental cost-effectiveness ratios (ICER) exceeded the Brazilian gross domestic product (GDP) per capita by three times in all proposed scenarios. The sensitivity of ICER showed an $88.4 \%$ chance of TT not being cost-effective. The impact of PI incorporation was negative and the conduct about this could have been different if a previous cost-effectiveness analysis had been conducted.
\end{abstract}

Economics; Pharmaceuticals; Decision Making; Hepatitis C; Protease Inhibitors

\author{
Correspondence \\ J. P. V. Rodrigues \\ Faculdade de Ciências Farmacêuticas de Ribeirão Preto, \\ Universidade de São Paulo. \\ Av. do Café s/n, Ribeirão Preto, SP 14040-903, Brasil. \\ jpvilela@fcfrp.usp.br \\ 1 Faculdade de Ciências Farmacêuticas de Ribeirão Preto \\ Universidade de São Paulo, Ribeirão Preto, Brasil. \\ 2 Faculdade de Ciências Farmacêuticas, Universidade Federal do \\ Rio Grande do Sul, Porto Alegre, Brasil. \\ 3 Departamento de Medicina, Universidade Federal de São \\ Carlos, São Carlos, Brasil. \\ 4 Faculdade de Medicina de Ribeirão Preto, Universidade de São \\ Paulo, Ribeirão Preto, Brasil.
}




\section{Introduction}

The viability of health systems - especially public ones with universal coverage - is related to the rational use of financial resources. Such resources are usually scarce to meet the demand of a population that presents an increasing life expectancy and is affected by chronic diseases that require continuous health care. Cost-effectiveness analysis is thus established as a necessary instrument for decision making processes. This analysis compares therapeutic options indicated for the same clinical condition considering costs and effectiveness, thus allowing maximum health benefits or that a greater number of patients are followed-up and benefited from the available resources 1 .

According to the World Health Organization (WHO), around 71 million people have chronic hepatitis C (CHC), and approximately 400,000 deaths occur annually from CHC complications worldwide 2 . In general, its clinical manifestations are observed in advanced stages of liver fibrosis that may range from zero (F0) to four (F4 or cirrhosis). Estimations state that up to $20 \%$ of $\mathrm{CHC}$ patients develop cirrhosis over 20-30 years of infection 3 .

In the United States, cost estimates for CHC-related complications were USD 24,755 patient/ year related to the care of refractory ascites, USD 25,595 patient/year in the first year post variceal hemorrhage, and USD 44,200 patient/year with care for patients diagnosed with hepatocellular carcinoma. The mean cost of each liver transplantation, i.e., the gold standard treatment for end-stage liver disease, was estimated at USD 201,110 4. The prevalence of individuals with hepatocellular carcinoma who have antibodies to hepatitis C virus (HCV) exceeds 60\% in different regions of the world, such as the United States, Europe, and Brazil. Sustained virological response (SVR), which represents no detection of the virus in the blood 12 or 24 weeks after treatment, reduces the incidence of CHC complications ${ }^{3}$.

Considering genotype 1 - the most prevalent type of HCV - the use of the dual therapy (DT) with ribavirin (RBV) and pegylated interferon (Peg-INF), the standard CHC treatment throughout the 2000s, was associated with a 40-50\% SVR rate 3 . Approved in 2011 by the U.S. Food and Drug Administration (FDA) for the treatment of CHC, the first-generation protease inhibitors (PI) boceprevir (BOC) and telaprevir (TVR) were the first possibility of direct therapy against HCV. TVR and BOC, in combination with RBV and Peg-INF $\alpha-2$ a or $\alpha-2 b$, are indicated for patients infected by HCV genotype 1 and act by inhibiting the NS3/4A viral protease and virus replication. Pre-marketing clinical trials showed SVR rates above $70 \% 5,6,7$.

In 2013, the first-generation PI were incorporated into the Brazilian Unified National Health System (SUS, in Portuguese) 8. Brazil is a developing country of continental dimensions that has a health public system that includes a specific viral hepatitis program. The triple therapies (TT) with BOC and TVR represented a direct cost to SUS, per treatment for 48 weeks, of about USD 18,000 and USD 15,600, respectively. Regarding the total number of treated patients from 2013 to 2016, the TT cost to SUS exceeded USD 100,000,000 9,10 (http://www.in.gov.br/web/guest/inicio, accessed on 18/Jun/2018).

However, these data are not enough to have evidence about these treatments. Up to what point can we invest in a promissory health technology? Moreover, how much should we invest? Who should be treated? In which conditions to treat someone? These are questions that help us to construct rational decision making and equitably improve health care. Cost-effectiveness analyses have been essential for decision making processes because of these questions - and the lack of answers to them. Several countries use this kind of analysis as synthesis of evidence to rationally incorporate new health technologies in their health systems. Thus, cost-effectiveness analysis alongside epidemiological analysis has been appropriated to generate robust evidence and to build efficient ways for decision making in health.

Given this context, the aim of this study was to perform cost-effectiveness analysis related to the inclusion of BOC and TVR in a clinical protocol to discuss the relevance and usefulness of this methodology in decision making. 


\section{Methods}

\section{Study design and ethical aspects}

This is a cost-effectiveness analysis from the perspective of a public health system. This analysis was proposed as part of a real-life study performed at the General Hospital of the Medical School of Ribeirão Preto, University of São Paulo, Ribeirão Preto, Brazil (HCFMRP-USP, in Portuguese), which included patients chronically infected with HCV genotype 111 . The main effectiveness and clinical data of this study are presented in Supplementary Table 1 (http://cadernos.ensp.fiocruz.br/ site/public_site/arquivo/suppl-e00036619_6733.pdf). The Research Ethics Committee of the cited hospital approved the study, approval n. 345,034.

\section{Cost and outcome}

The time horizon of the analysis was 60 weeks, ending in 2016 ( 48 weeks of treatment plus 12 weeks until the last viral load test result, indicating the main outcome of the therapy). The costs collected were related to the year 2015 and the conversion from reais to dollar was made according to the exchange rate provided by the Central Bank of Brazil, being USD 1.00 = BRL 3.34 (http://www4.bcb. gov.br/pec/taxas/port/ptaxnpesq.asp?id=txcotacao, accessed on 20/Jun/2018). The pharmacoeconomic analysis was structured from direct medical costs from SUS 12 . Initially, cost and effectiveness data - understood as cure of the disease or SVR - of the therapies considered for this analysis were collected: DT with Peg-INF $\alpha$-2a and RBV; TT with Peg-INF $\alpha$-2a, RBV and BOC; TT with Peg-INF $\alpha-2 a$, RBV and TVR.

Cost data were based on information provided in the official Brazilian government journal (http://www.in.gov.br/web/guest/inicio, accessed on 18/Jun/2018), and on a study conducted in Brazil that used TVR, BOC, Peg-INF $\alpha-2 \mathrm{a}$ and RBV costs in its analysis 9 . The choice for Peg-INF $\alpha-2 \mathrm{a}$ occurred because all patients included in the study conducted at HCFMRP-USP were treated with this drug. The calculations were performed considering 48 weeks of treatment for the three regimens, as recommended in the guidelines 3,8 , and $70 \mathrm{~kg}$ as body weight for the definition of the number of RBV tablets.

The mean costs of treatment re gimens for CHC were the actual amounts paid by SUS 9 (http:// www.in.gov.br/web/guest/inicio, accessed on 18/Jun/2018), whereas the maximum costs were defined based on consolidated tables from the Regulation Council of the Medication Market (CMED, in Portuguese). CMED, which is linked to the Brazilian Health Regulatory Agency (Anvisa, in Portuguese), establishes the maximum costs for drugs for public purchases in Brazil 13. Considering the calculation of the minimum costs, it was verified how much each mean cost represented (\%) in relation to the maximum cost defined by CMED. The minimum cost was this same percentage in relation to the mean or actual cost.

The SVR or cure rate represented health benefits in this study. The mean, maximum and minimum values of SVR rates for each of the regimens were also calculated from the effectiveness data of different real-life studies. To calculate the mean SVR for the DT with Peg-INF $\alpha-2$ a and RBV, five studies were considered, two of them performed in Brazil 14,15,16,17,18. The calculations of mean effectiveness or mean SVR rates of the TT were based on the response rates of the study conducted at HCFMRP-USP and six other studies, among these, two multicenter prospective studies conducted in Europe 19,20,21,22,23,24. Subsequently, the standard deviation (SD) of the five SVR rates from the DT studies, the seven SVR rates resulting from the TVR treatment and the seven effectiveness rates with BOC were calculated. Minimum and maximum effectiveness values were calculated by subtracting and adding the SD to the means of SVR, respectively.

\section{Cost-effectiveness analysis}

The cost-effectiveness ratio (CER) indicates the cost per cure achieved (ratio between treatment cost and cure rate of the treatment). The minimum, mean and maximum CER of each of the regimens were defined by dividing the minimum, mean and maximum cost values by the respective minimum, mean 
and maximum SVR rates. In turn, the incremental cost-effectiveness ratio (ICER) represents the cost involved in extra cure when using PI therapies ${ }^{12}$. The minimum, mean and maximum ICER for TT were calculated according to Equation (1):

$$
\text { ICER }=(\text { Cost of TT }- \text { Cost of DT }) \div(T T S V R-D T S V R)
$$

For both the CER and ICER calculations, SVR rates were considered in absolute value rather than percentage. The value of the Brazilian gross domestic product (GDP) per capita (USD 8,645) referring to the 2015 consolidation was considered for the cost effectiveness threshold. This value was triplicate for the conformation of the threshold, as recommended by the Brazilian Network for Health Technology Assessment (REBRATS, in Portuguese) 25.

\section{Sensitivity analysis of results}

With the help of the statistical software Minitab version 17 (http://www.minitab.com), the descriptive statistics data (calculated costs and outcomes) were summarized in the representation of means, SD, minimum, and maximum values. Descriptive statistics were important for the definition of truncation limits for the probability density curves for CER and ICER. Regarding the sensitivity analyses of CER and ICER, a Monte Carlo simulation was performed for the uncertainties about cost and effectiveness variability for therapy with RBV and Peg-INF $\alpha-2 \mathrm{a}$ and for TT. The minimum, mean and maximum values of effectiveness and cost of the three treatment regimens were used as parameters for data distribution.

The software @Risk version 7 (https://www.palisade.com) was used for the Monte Carlo analysis. The variation followed a predefined probability distribution curve for the study data, being normal distribution for costs and triangular distribution for effectiveness rates. Triangular distribution is recommended when the variable refers to a rate 12 .

Net monetary benefits (NMB) can be interpreted as the monetary benefit for each additional cure achieved, considering the sensitivity of the results of the ratio of incremental cost-effectiveness. NMB analyses that considered relative effectiveness (RE) were performed for each CHC therapy in Excel 2010 (https://products.office.com/), and calculated by Equation (2):

$$
N M B=(\text { Ceiling price for therapy } \times R E(T T \div D T))-\text { Cost of therapy }
$$

The RE was calculated according to the sensitivity of the effectiveness: TT effectiveness divided by DT effectiveness. Variation in NMB results refers to the possible costs that hepatitis therapies may have to SUS, interpreted as the willingness to pay. Thus, when the variation in the cost refers to negative NMB, it represents a non-compensatory investment, and when referring to positive NMB values it is a valuation that compensates investment. The cost-effectiveness threshold was used as a comparator for the NMB sensitivity, like a ceiling price for investment. The probability for TT to be cost-effective was calculated considering the limitation regarded by the threshold.

Sub-analysis about the use of TT according liver fibrosis stage was performed. Data from five previously published studies were used to make the weighted mean, considering response rates and number of patients to each fibrosis degree. After this, another response rates weighted means for F0/ F1/F2 and for F3/F4 groups was made. The studies were an Italian multicenter real-life study, and four pre-marketing studies that were essential for the approval of BOC and TVR 5,6,7,26,27. Moreover, data from the study of which the pharmacoeconomic analysis treated in this article was part of were also considered. Thus, these data composed the expected value of perfect diagnostic information (EVPDI) analysis for the cost-effectiveness profile of TT. The programs used for the analyses and graphs were Excel 2010 and Origin Pro 8 (https://www.originlab.com). 


\section{Results}

Of the 115 patients followed up in phase IV of the trial conducted at HCFMRP-USP, 103 patients were treated with TVR (SVR $=62.1 \%)$ and 12 with BOC (SVR $=58.3 \%)$. The mean cost of BOC and TVR therapies was USD 35,573 and USD 24,857 per CHC cure, respectively. The incremental mean cost for further cure of CHC was USD 157,295 for BOC, and USD 56,976 for TVR. When the means of cost and SVR were weighted by the number of patients treated by BOC and TVR, the mean cost for cure was USD 29,638, and for further cure it was USD 87,285 - which could reach USD 158,522 (Supplementary Tables 2 and 3: http://cadernos.ensp.fiocruz.br/site/public_site/arquivo/ suppl-e00036619_6733.pdf).

According to the probabilities of the CER for CHC treatment, the sensitivity analysis showed that there is an $88.2 \%$ chance of treatment with TT (weighted mean of the TVR or BOC therapy data) presenting a higher cost per cure than treatment with Peg-INF $\alpha-2 \mathrm{a}$ and RBV. The mean of the differences between the cure cost of TT and the cost per cure of DT was USD 18,172, and the maximum value that a difference in cost per cure could reach was USD 60,000 (Figure 1).

According to the sensitivity analysis of the ICER comparing TT (weighted mean) with DT, there is a $2.8 \%$ likelihood of treatments comprising TVR or BOC to be dominant in cost-effectiveness

\section{Figure 1}

Sensitivity analysis of the difference between cost-effectiveness ratios for treatment with triple therapies compared to dual therapy.

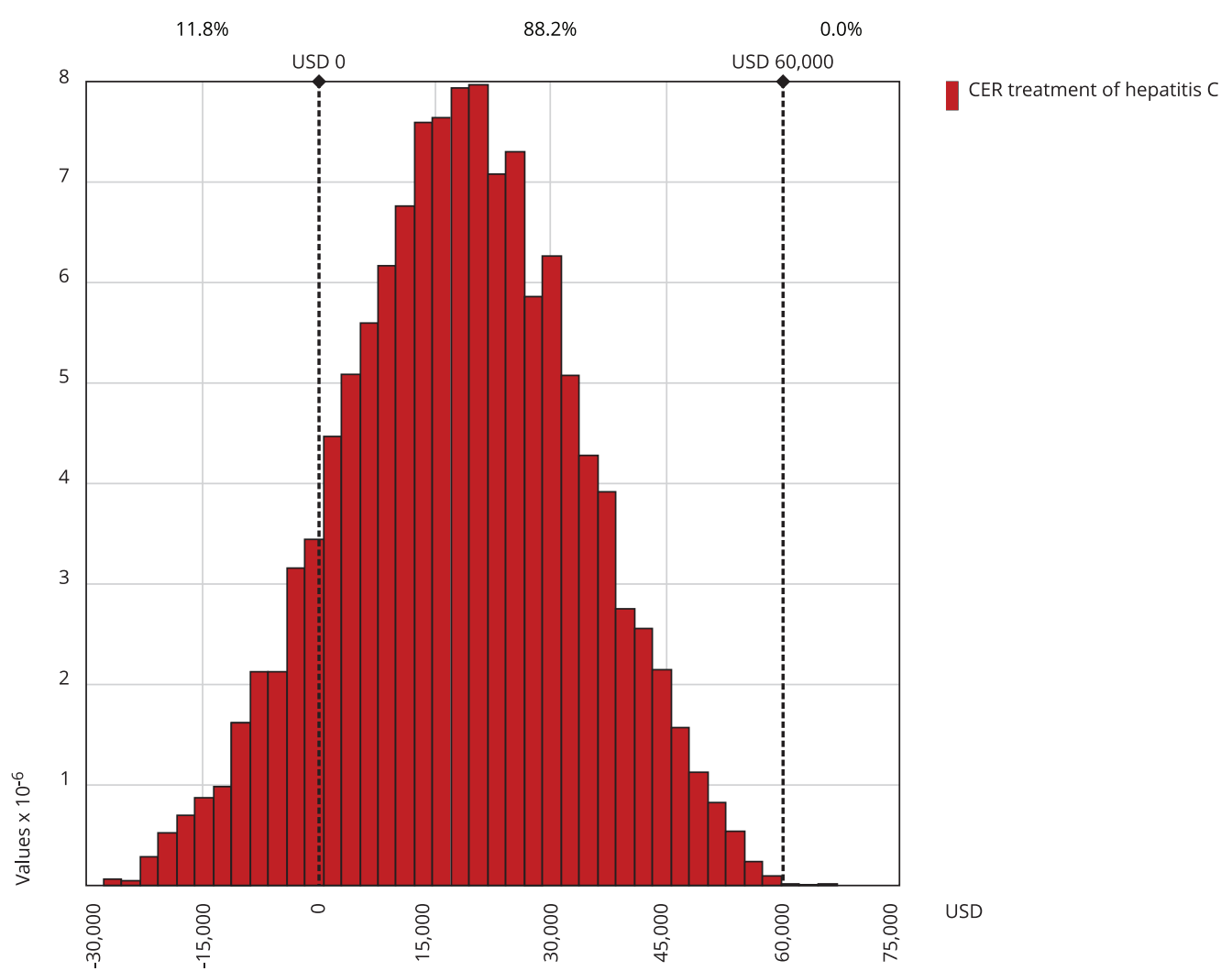

Note: The percentages of chances of the differences in cost-effectiveness ratios between treatment with triple therapies and dual therapy are represented, according to the probability distributions, considering 10,000 Monte Carlo iterations. 
analysis (minimum ICER of USD -85,837). The other 97.2\% of the ICER values are within a range of positive values and required analysis by the cost-effectiveness threshold. With the cost sensitivity and effectiveness variation, the mean value for the ICER was USD 85,278, and the maximum value was USD 456,586 (Figure 2a). Among the possible positive ICER values for the CHC treatment with TT compared to DT, it was verified that there is an $11.6 \%$ chance of these values being below the cost-effectiveness threshold. Consequently, there is an $88.4 \%$ chance of TT not being cost-effective (Figure 2b).

The analysis of NMB showed that the RE required is almost 0.80 (crossing point between blue and red lines, Figure 3a), i.e., TT should be $80 \%$ more effective than DT for TT is more cost-effective. Even providing a perfect scenario for the response of TT compared to DT, when TT have the best NMB chance and DT the worst, the result was that TT should be 70\% better than DT for the effectiveness of TT to be better than DT (red dotted line, Figure 3a). Most of the possible results for the NMB as the ceiling price variation were negative, representing $86.6 \%$ of all results. After USD 71,648 as willingness to pay only positives values for NMB were achieved (almost three times the cost-effectiveness threshold). It is noteworthy that the greatest chances were for a negative NBM approximately $83 \%$ (blue dots below x-axis, Figure $3 \mathrm{~b}$ ).

NMB was also analyzed according to ceiling price and RE variations. Even if TT were 100\% better than DT in effectiveness, TT would not a cost-effective strategy for a ceiling price greater than USD

\section{Figure 2}

Sensitivity analysis of the incremental cost-effectiveness ratio for treatment with triple therapies.

2a)

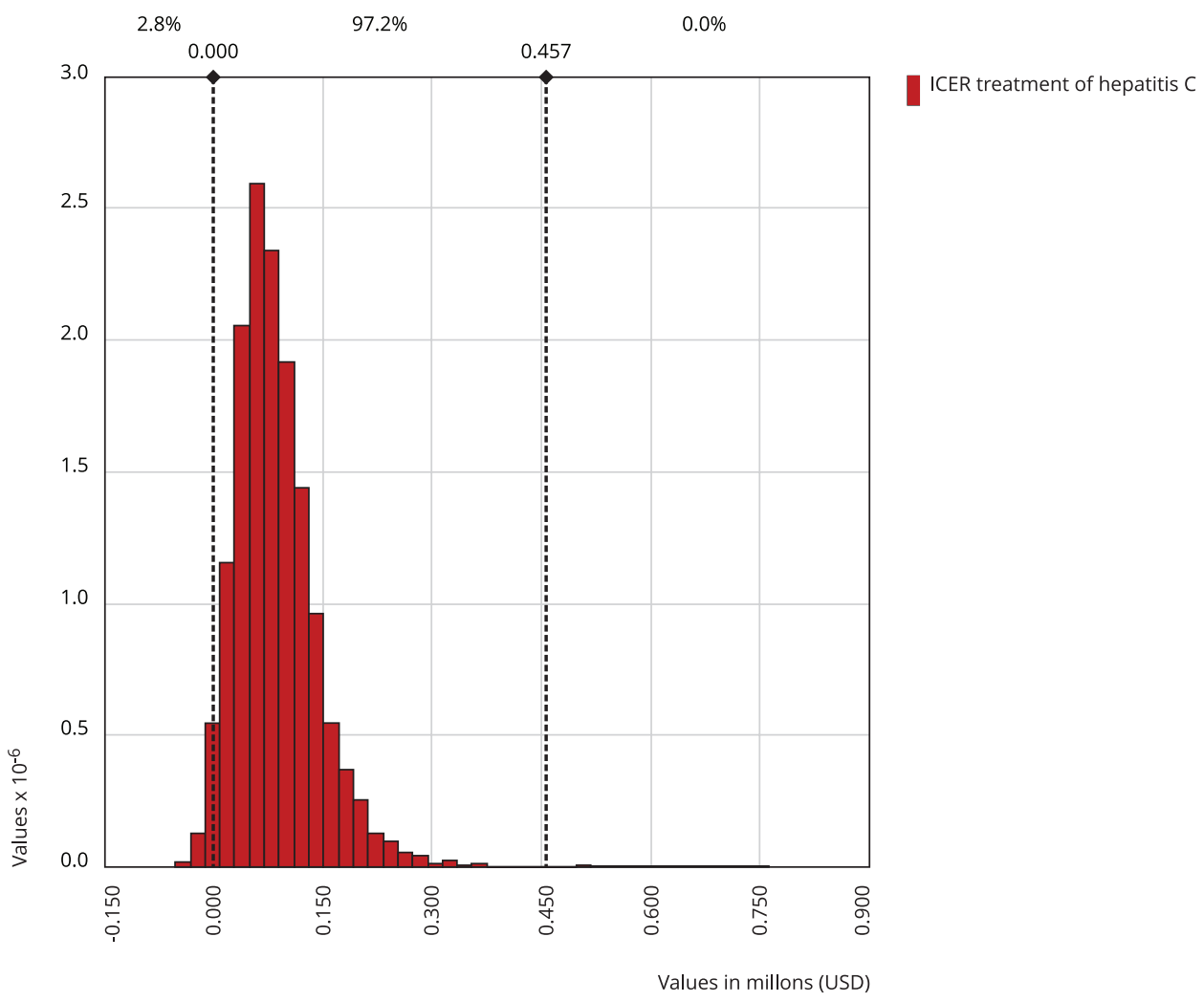

(continues) 
2b)

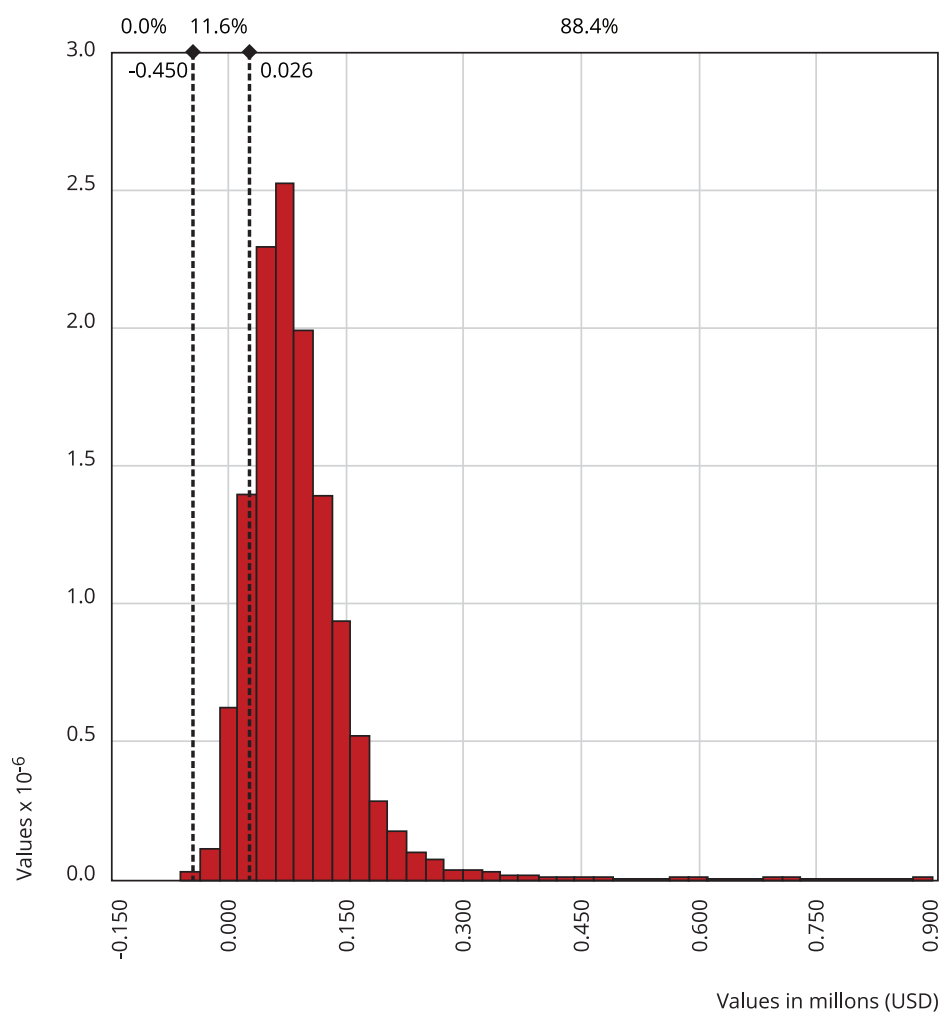

ICER treatment of hepatitis $C$

ICER: incremental cost-effectiveness ratio.

Note: The percentages of chances and their respective values of the ICER are represented, according to the probability distributions, considering 10,000 Monte Carlo iterations (Figure 2a). ICER sensitivity analysis for treatment with triple therapies in relation to the dual therapy regimen (Figure $2 b$ ). ICER sensitivity analysis for treatment with triple therapies in relation to the double regimen, considering the cost-effectiveness threshold: the value of USD 0.026 million represents the cost-effectiveness threshold (three times the gross domestic product per capita in the year 2015).

14,413. Considering that the mean price of TT was USD 16,661, it would be impossible for TT to be cost-effective strategy, even with 100\% RE.

Regarding the sub-analysis that considered the use of TT considering the liver fibrosis stage, the total number of individuals of all studies with mild/moderate liver fibrosis (F0/F1/F2) represented 1,733 patients (effectiveness rate per weighted mean was 72.4\%); and 1,014 individuals had advanced fibrosis (F3 or F4) (effectiveness rate was 58.4\%). The prevalence of F0/F1/F2 individuals was 63\%.

Up to $42 \%$ of prevalence of F0/F1/F2 would be compensatory to treat none individuals with CHC, over this point it would be cost-effective to treat all patients (NMB treat all) up to $82 \%$ of prevalence of mild/moderate fibrosis. Even in the best-case scenario that considers the supply of diagnosis and pharmacological therapy to all CHC patients (green line, Figure 4), treating all individuals would not be a cost-effective strategy if the prevalence of patients with advanced fibrosis exceeds $94 \%$ (negative NMB) (Figure 4). 
Figure 3

Net monetary benefits (NMB) for dual and triple therapies.

3a) Ceiling price

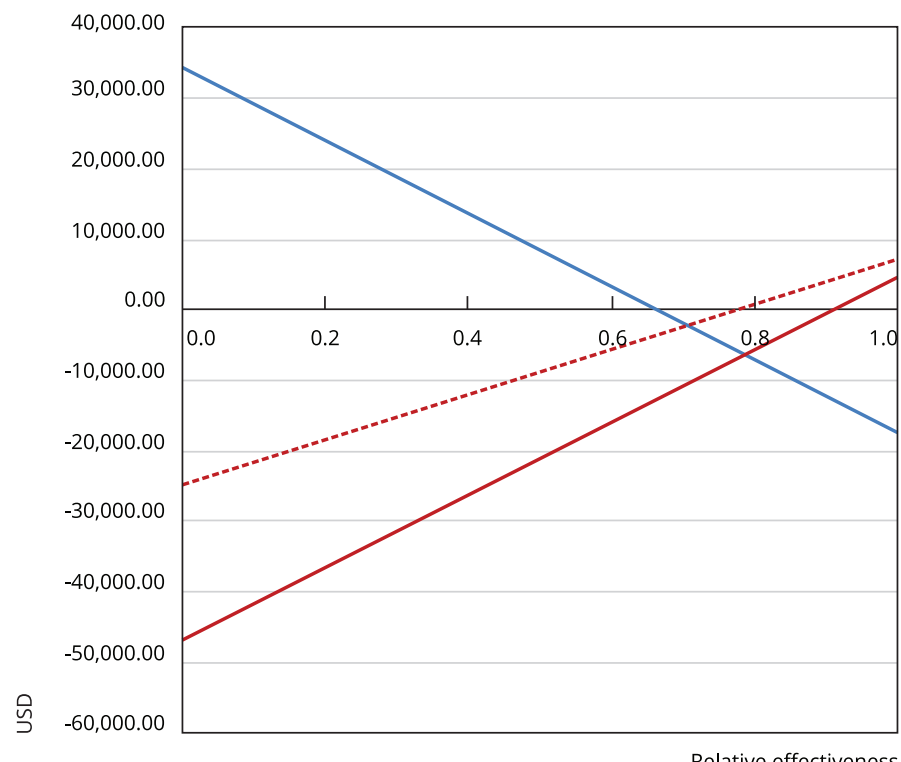

NMB DT

NMB TT

Expextancy of better NMB

3b) NMB

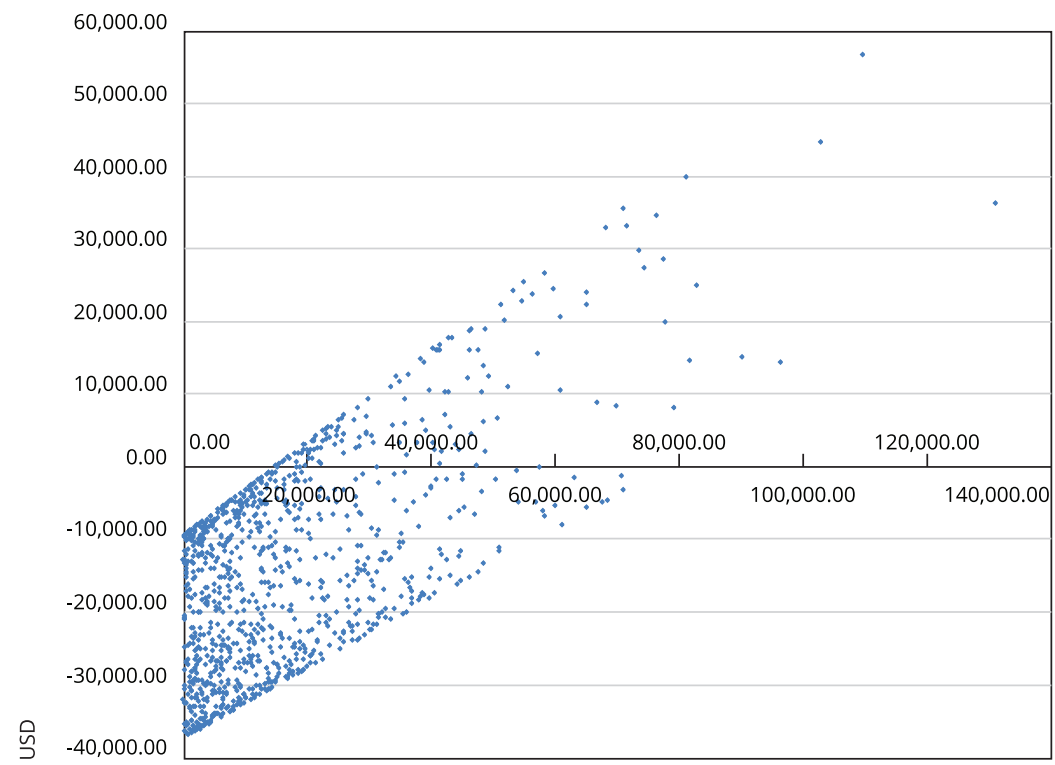

Ceiling price (USD)

DT: dual therapy; TT: triple therapies.

Note: NMB for the dual therapy and triple therapies and the expectancy for the better NMB possible according to the relative effectiveness and cost variations (Figure 3a). Expected NMB values in relation to the willingness to pay for the triple therapies (Figure 3b). 


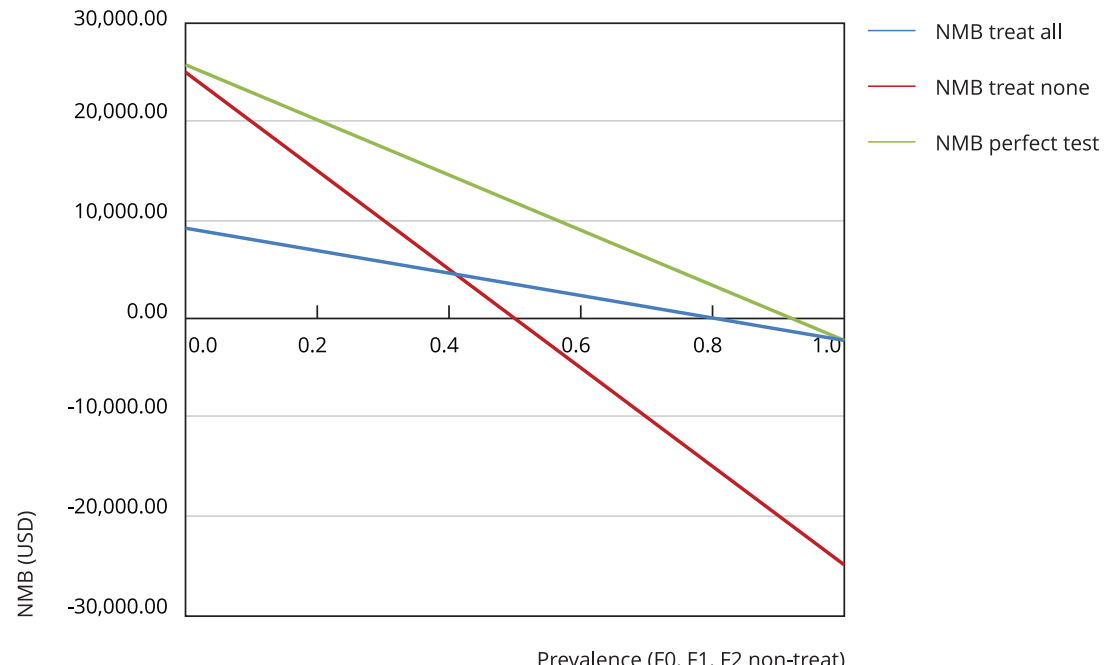

NMB: net monetary benefits.

Note: EVPDI analysis for conceptualizing the NMB considering patients treated with triple therapies, fibrosis staging and effectiveness according fibrosis staging.

\section{Discussion}

In Brazil, approximately $70 \%$ of the population depend on public health services and pharmacoeconomics should be mandatory for inclusion of new health technologies in SUS. The incorporation of first-generation PI into SUS was supported by phase III clinical trials 5,6,7,26, but our results based on real-life data suggest that this strategy was unfeasible for the reality of SUS.

Considering the minimum, mean and maximum costs, we verified that BOC or TVR therapies presented minimum values for cost per cure greater than the mean cost per cure of DT, moreover, the cost per extra cure of both was always higher than the cost-effectiveness threshold, even when considering the minimum cost and maximum effectiveness. The results were similar when considering TT without description of the specific regimen, highlighting that the minimum cost per extra cure reached almost double the cost-effectiveness threshold - USD 25,936. Sensitivity analyses showed that TT are more likely to have a higher cost per cure (CER) and extra cure (ICER) than DT, reaching more than $80 \%$ of the probabilities.

The incorporation of TT for the treatment of CHC had an ICER value that exceeded by three times the GDP per capita value for all scenarios, considering the variation of effectiveness and minimum, maximum and mean costs. Considering that this threshold is overestimated for Brazil, the reality becomes even worse 11,28 .

The cost-effectiveness analysis conducted did not consider the adverse drug events. Drugs used in DT are part of TT 3,8, we can thus infer that the use of TT results in the same adverse reactions of DT, as well as other reactions directly associated to TVR or BOC. Therefore, adverse events such as hematologic reactions are more common with TT use 5,6. If the costs related to the management of these reactions had been considered, our results indicating the incorporation of TVR and BOC as a non-cost-effective conduct would be even more evident.

To show results regarding the variation related to the disease staging was important for the sensitivity analysis. For ethical reasons, pre-marketing trials usually include patients at the initial 
stages of $\mathrm{CHC}$ and with better health conditions than real-life studies, thus having a favorable clinical profile. Therefore, only real-life studies were included for the sensitivity analysis in our study. Our major study - at HCFMRP-USP - included 50.4\% of cirrhotic individuals. In turn, the ILLUMINATE phase III study, which was important for the approval of TVR, included about $10 \%$ of cirrhotic patients 7 .

Through a cost-effectiveness analysis that involved the Markov model, long-term cost estimates and quality adjusted life years (QALYs), further use of indicators such as ICER and NMB, Chen \& Chen 28 showed that the all-oral regimen with new direct acting antivirals is related with good longterm health and economic benefit for patients infected with HCV genotype 1 in relation to therapy based on Peg-INF and RBV. Another study also used similar strategies to our study and found that extending the $\mathrm{CHC}$ therapy to patients at an early stage of $\mathrm{HCV}$ infection would be cost effective from the perspective of the Italian Healthcare System 29. These studies highlight the relevance of cost-effectiveness analysis.

According to the 2013 Brazilian guideline for CHC treatment 8 , only patients with advanced liver fibrosis (F3 or F4) could be treated with TT, except for cases with other specific manifestations or comorbidities (these few cases could be F0, F1 or F2). In the same year, SUS published a supplement to the guideline that allowed the treatment of $\mathrm{F} 2$ patients since the examination had been performed more than 3 years ago. Thus, F3 or F4 patients were the most treated. However, the strategy of inclusion of PI in the Brazilian guideline did not prove to be a cost-effective decision for most of the proposed scenarios, even if individuals with early-stage fibrosis were treated with TT. The recommendations of the guideline certainly implied the effectiveness of TT since patients with a $\mathrm{mild} /$ moderate fibrosis stage are representative of an advanced stage and having a decreased chance to reach SVR. Thus, the higher chance of SVR in mild/moderate CHC stages is coherent with the results found in our analysis involving the use of TT according to liver fibrosis staging. Health policies could consider TT as cost-effective to treat all CHC patients if the prevalence of F0/F1/F2 ranged from $42 \%$ to $82 \%$. If the prevalence was above $82 \%$, the costs to treat all would not be compensatory because the NMB is negative from this point on.

The costs and effectiveness associated with CHC treatment are considered one of the major discussion of health policies around the world. In the United States, it is estimated that only $15 \%$ of the population chronically infected with HCV has been treated to date. This situation has generated discussions about new drug financing strategies to increase the access to treatment 30 .

In addition to already mentioned limitations, the pharmacoeconomic analysis proposed did not consider indirect costs involved such as loss of productivity and death. The best way to establish a costeffectiveness threshold is by defining willingness-to-pay models 31 . The cost-effectiveness threshold is understood as a limitation to pharmacoeconomic analyses in low- and middle-income countries. There are no definitions for the threshold that have even accuracy for the gold standard outcome to evaluate health technologies, such as QALY. Thus, as recommended for Latin America, the threshold used in our study was expanded by the National Commission for Incorporation of Technologies in SUS for simple outcomes in health and considered as gold standard for a particular disease, in this case we used for RVS 32,33. Despite the limitations, this work is relevant for analyzing the incorporation of drugs associated with high costs into a public health system. The effectiveness data of this and other phase IV studies indicated that premarketing trials overestimated the effectiveness of TT 19,20,21,34.

Our results showed that sensitivity of ICER and PI NMB were above the investment threshold for BHPS and suggest that cost-effectiveness analysis is important for health systems. The Brazilian Ministry of Health approved the withdrawal of the first-generation IP from its therapeutic arsenal in 2015, about two years after inclusion. At this time, more effective, safe and cost-effective drugs were included in the Brazilian protocol 35. Although this conduct has been a prompt answer to innovations of the pharmaceutical market, it was in line with the results of this study, which indicated that the inclusion of IP was not cost-effective.

Hepatitis $\mathrm{C}$ remains an important public health problem worldwide. Although there are currently other options for direct action drug therapies, the cost is still a limiting factor for access to CHC treatment. 


\section{Conclusion}

In conclusion, this study evidenced that the incorporation of first-generation PI into SUS was not a cost-effective strategy in several scenarios. However, it could be a reasonable strategy in other epidemiological realities. The results showed that cost-effectiveness analyses based on real-life data are fundamental to generate evidence and propose a rational decision making process for $\mathrm{CHC}$ therapies. In fact, the decision of disinvestment in old treatments by the incorporation of new drugs for $\mathrm{CHC}$ in health systems can waste large sums of money when variations related to the epidemiological landscape and cost-effectiveness sensitivities are left unconsidered.

\section{Contributors}

J. P. V. Rodrigues contributed to the study design and planning, data collection, analysis and interpretation, drafting, and revision. M. S. Cazarim contributed to the study design and planning, data analysis and interpretation, drafting, and revision. S. G. F. Chachá contributed to the study design and planning, data collection, drafting, and revision. A. L. C. Martinelli contributed to the study design, planning and management, drafting, and revision. L. R. L. Pereira contributed to the study design, planning and management, data analysis and interpretation, drafting, and revision.

\section{Additional informations}

ORCID: João Paulo Vilela Rodrigues (0000-00025785-1418); Maurílio de Souza Cazarim (00000002-2826-5903); Silvana Gama Florencio Chachá (0000-0002-2054-0771); Ana de Lourdes Candolo Martinelli (0000-0002-1713-9039); Leonardo Régis Leira Pereira (0000-0002-8609-1390).

\section{Acknowledgments}

The authors are thankful to the physicians and other health workers of General Hospital of the Medical School of Ribeirão Preto, University of São Paulo, who contributed to the accomplishment of this work. We would like to thank São Paulo State Research Foundation (FAPESP) for providing the scholarship for the author M. S. Cazarim (grant n. 2017/21240-0 from January 2018 to August 2018 and grant n. 2016/03584-1 from August 2016 to August 2019). And to the Brazilian Graduate Studies Coordinating Board (Capes).

\section{References}

1. Whyte S, Dixon S, Faria R, Walker S, Palmer S, Sculpher M, et al. Estimating the cost-effectiveness of implementation: is sufficient evidence available? Value Health 2016; 19:138-44.

2. World Health Organization. Glob-al Hepatitis Report, 2017. https://apps.who. int/iris/bitstream/handle/10665/255016/ 9789241565455-eng.pdf;jsessionid $=186513$ DC0DD7B7D739A0925E36327BF5?sequen $\mathrm{ce}=1$ (accessed on 20/Dec/2018).

3. European Association for the Study of the Liver. EASL clinical practice guidelines: management of hepatitis $\mathrm{C}$ virus infection. J Hepatol 2014; 60:392-420.

4. El Khoury AC, Klimack WK, Wallace C, Razavi $\mathrm{H}$. Economic burden of hepatitis C-associated diseases in the United States. J Viral Hepat 2012; 19:153-60.

5. Bacon BR, Gordon SC, Lawitz E, Marcellin P, Vierling JM, Zeuzem S, et al. Boceprevir for previously treated chronic HCV genotype 1 infection. N Engl J Med 2011; 364:1207-17.

6. Jacobson IM, McHutchison JG, Dusheiko G, Di Bisceglie AM, Reddy KR, Bzowej NH, et al. Telaprevir for previously untreated chronic hepatitis C virus infection. N Engl J Med 2011; 364:2405-16.

7. Sherman KE, Flamm SL, Afdhal NH, Nelson DR, Sulkowski MS, Everson GT, et al. Response-guided telaprevir combination treatment for hepatitis $\mathrm{C}$ virus infection. $\mathrm{N}$ Engl J Med 2011; 365:1014-24.

8. Ministério da Saúde. Protocolo clínico e diretrizes terapêuticas para hepatite viral C e coinfecções: genótipo 1 do HCV e fibrose avançada. Suplemento 2. Brasília: Ministério da Saúde; 2013.

9. Mattana ABB. Efetividade e segurança dos inibidores de protease para o tratamento da hepatite C [Masters Thesis]. Porto Alegre: Universidade Federal de Ciências da Saúde de Porto Alegre; 2016.

10. Callefi LA, Villela-Nogueira CA, de Barros Tenore S, Carnaúba-Júnior D, Coelho HSM, Pinto PTA, et al. Effectiveness and safety of first-generation protease inhibitors in realworld patients with hepatitis $C$ virus genotype 1 infection in Brazil: a multicenter study. Clinics (São Paulo) 2017; 72:378-85 
11. Chachá SGF, Rodrigues JPV, Araújo RC, Pereira LRL, Villanova MG, Souza FF, et al. First-wave protease inhibitors for hepatitis C genotype 1 treatment: a real-life experience in Brazilian patients. Rev Soc Bras Med Trop 2018; 51:146-54.

12. Rascati KL. Essentials of pharmacoeconomics. 2nd Ed. Baltimore: Lippincott Williams \& Wilkins; 2014

13. Câmara de Regulação do Mercado de Medicamentos. Preços máximos de medicamentos por princípio ativo, para compras públicas. http://portal.anvisa.gov.br/listas-de-precos/ compras-publicas (accessed on 20/Jun/2018).

14. Parise E, Cheinquer H, Crespo D, Meirelles A, Martinelli A, Sette H, et al. Peginterferon alfa-2a (40KD) (PEGASYS ${ }^{\circledR}$ ) plus ribavirin (COPEGUS ${ }^{\circledR}$ ) in retreatment of chronic hepatitis $\mathrm{c}$ patients, nonresponders and relapsers to previous conventional interferon plus ribavirin therapy. Braz J Infect Dis 2006; 10:11-6.

15. McHutchison JG, Lawitz EJ, Shiffman ML, Muir AJ, Galler GW, McCone J, et al. Peginterferon alfa-2b or alfa-2a with ribavirin for treatment of hepatitis C infection. N Engl J Med 2009; 361:580-93.

16. Ascione A, De Luca M, Tartaglione MT, Lampasi F, Di Costanzo GG, Lanza AG, et al. Peginterferon alfa-2a plus ribavirin is more effective than peginterferon alfa- $2 b$ plus ribavirin for treating chronic hepatitis $\mathrm{C}$ virus infection. Gastroenterology 2010; 138:116-22.

17. Rumi MG, Aghemo A, Prati GM, D’Ambrosio $\mathrm{R}$, Donato MF, Soffredini R, et al. Randomized study of peginterferon-2a plus ribavirin vs peginterferon-2b plus ribavirin in chronic hepatitis C. Gastroenterology 2010; 138:10815.

18. Silva GF, Nogueira CAV, Mello CEB, Soares EC, Coelho HS, Ferreira PR, et al. Peginterferon plus ribavirin and sustained virological response rate in $\mathrm{HCV}$-related advanced fibrosis: a real life study. Braz J Infect Dis $2014 ; 18: 48-52$.

19. Salmerón J, Vinaixa C, Berenguer R, Pascasio JM, Ruano JJS, Serra MA, et al. Effectiveness and safety of first-generation protease inhibitors in clinical practice: hepatitis C virus patients with advanced fibrosis. World J Gastroenterol 2015; 21:9163-74.

20. Bonnet D, Guivarch M, Bérard E, Combis JM, Remy AJ, Glibert A, et al. Telaprevir- and boceprevir-based tritherapies in real practice for F3-F4 pretreated hepatitis $\mathrm{C}$ virus patients. World J Hepatol 2014; 6:660-9.

21. Price JC, Murphy RC, Shvachko VA, Pauly MP, Manos MM. Effectiveness of telaprevir and boceprevir triple therapy for patients with hepatitis $\mathrm{C}$ virus infection in a large integrated care setting. Dig Dis Sci 2015; 59:3043-52.

22. Almeida PR, Fonseca CB, Koch VW, Souza AM, Feltrin AA, Tovo CV. Triple therapy in chronic hepatitis C: initial series in a public health program in the South of Brazil. Arq Gastroenterol 2015; 52:14-7.
23. Vo KP, Vutien P, Akiyama MJ, Vu VD, Ha NB, Piotrowski JI, et al. Poor sustained virological response in a multicenter real-life cohort of chronic hepatitis $\mathrm{C}$ treated with pegylated interferon and ribavirin plus telaprevir or boceprevir. Dig Dis Sci 2015; 60:1045-51.

24. Werner CR, Franz C, Egetemeyr DP, Beck R, Malek NP, Lauer UM, et al. First-generation protease inhibitor-triple therapy: SVR 24, safety, and predictors of response in a large single center cohort. Virol J 2015; 12:37.

25. Departamento de Ciência e Tecnologia, Secretaria de Ciência, Tecnologia e Insumos Estratégicos, Ministério da Saúde. Diretrizes metodológicas: diretriz de avaliação econômica. 2a Ed. 2014. http://rebrats.saude.gov.br/diretrizesmetodologicas (accessed on 25/Jun/2018).

26. Poordad F, McCone Jr. J, Bacon BR, Bruno S, Manns MP, Sulkowski MS, et al. Boceprevir for untreated chronic HCV genotype 1 infection. N Engl J Med 2011; 364:1195-206.

27. Ascione A, Adinolfi LE, Amoroso P, Andriulli A, Armignacco O, Ascione T, et al. Boceprevir or telaprevir in hepatitis $\mathrm{C}$ virus chronic infection: the Italian real life experience. World J Hepatol 2016; 8:949-56.

28. Chen H, Chen L. Estimating cost-effectiveness associated with all-oral regimen for chronic hepatitis C in China. PLoS One 2017; 12:e0175189.

29. Ruggeri M, Romano F, Basile M, Coretti S, Rolli FR, Drago C, et al. Cost-effectiveness analysis of early treatment of chronic HCV with sofosbuvir/velpatasvir in Italy. Appl Health Econ Health Policy 2018; 16:711-722.

30. Trusheim MR, Cassidy WM, Bach PB. Alternative state-level financing for hepatitis C treatment: the "Netflix Model". JAMA 2018; 320:1977-8.

31. Culyer AJ. Cost-effectiveness thresholds in health care: a bookshelf guide to their meaning and use. Health Econ Policy Law 2016; 11:41532 .

32. Cazarim MS, Gonçalves ACO, Maduro LCS, Pereira LRL. Perspectives of pharmacoeconomics to improve access to the Brazilian Public Health System. Journal of Applied Pharmaceutical Sciences 2016; 3(S1):3-6.

33. Santos AS, Guerra-Junior AA, Godman B, Morton A, Ruas CM. Cost-effectiveness thresholds: methods for setting and examples from around the world. Expert Rev Pharmacoecon Outcomes Res 2018; 18:27788.

34. Lobato CMO, Balassiano N, Hyppolito EB, Sanchez-Lermen RLP, Signorelli IV, Nicacio MYT, et al. Effectiveness of first-wave protease inhibitors in hepatitis $C$ virus genotype 1 infection: a multicenter study in Brazil. Rev Soc Bras Med Trop 2018; 51:14-20.

35. Ministério da Saúde. Protocolo clínico e diretrizes terapêuticas para hepatite viral $\mathrm{C}$ e coinfecções. Brasília: Ministério da Saúde; 2015. 


\section{Resumo}

A análise de custo-efetividade tem sido essencial para a tomada de decisões em saúde. Diversos países utilizam esse tipo de análise como sintese das evidências para incorporar as tecnologias em saúde. Os inibidores de protease (IPs) boceprevir (BOC) e telaprevir (TVR) são indicados para o tratamento da hepatite $C$ crônica e foram incorporados nas diretrizes internacionais. Os ensaios clínicos pré-marketing demonstraram taxas mais altas de resposta virológica sustentada em relação às terapias anteriores, mas a incorporação dos IPs gerou um impacto financeiro significativo. $O$ estudo teve como objetivo discutir a relevância da análise de custo-efetividade, através de um estudo que envolveu a inclusão de IPs em um protocolo clínico. A análise fez parte de um estudo de vida real que incluiu pacientes com infecção pelo vírus da hepatite C, genótipo 1, tratados em um hospital universitário terciário no Brasil. As terapias triplas (TTs) com ribavirina ( $R B V)$, peg-interferon $\alpha-2 a(P e g-I N F \quad \alpha-2 a)$ e BOC ou TVR foram comparadas às terapias duplas com RBV e Peg-INF $\alpha-2 a$. A análise de sensibilidade da custo-efetividade indicou odds de 88,2\% de TTs apresentarem custo mais elevado por paciente curado. Em todos os cenários propostos, as razões de custo-efetividade incremental (ICERs) superaram em três vezes o produto interno bruto (PIB) per capita brasileiro. A sensibilidade da ICER mostrou probabilidade de 88,4\% das TTs não serem custo-efetivas. O impacto da incorporação dos IPs foi negativo, e a conduta teria sido diferente se tivesse sido realizada uma análise prévia de custo-efetividade.

Economia; Preparações Farmacêuticas;

Tomada de Decisões; Hepatite C;

Inibidores de Proteases

\section{Resumen}

El análisis de coste-efectividad ha sido esencial para la toma de decisiones en salud. Diversos países utilizan este tipo de análisis como sintesis de evidencias para incorporar tecnologías en salud. Los inhibidores de proteasa (IPs) boceprevir (BOC) y telaprevir (TVR) se indican para el tratamiento de la hepatitis $C$ crónica y fueron incorporados en directrices internacionales. Los ensayos clinicos pre-marketing demostraron tasas más altas de respuesta virológica sostenida, respecto a las terapias anteriores, pero la incorporación de los IPs generó un impacto financiero significativo. El objetivo del estudio fue discutir la relevancia del análisis de coste-efectividad, a través de un estudio que implicó la inclusión de IPs en un protocolo clínico. El análisis formó parte de un estudio de vida real que incluyó a pacientes con infección por el virus de la hepatitis $C$, genotipo 1, tratados en un hospital universitario terciario en Brasil. Las terapias triples (TTS) con ribavirina $(R B V)$, peg-interferon $\alpha-2 a($ Peg-INF $\alpha-2 a)$ y BOC o TVR se compararon con las terapias dobles con $R B V$ y Peg-INF $\alpha-2 a$. El análisis de sensibilidad del coste-efectividad indicó odds de 88,2\% de que las TTs presentaran un coste más elevado por paciente curado. En todos los escenarios propuestos, las razones de coste-efectividad incremental (ICERs) superaron tres veces el producto interno bruto (PIB) per cápita brasileño. La sensibilidad de la ICER mostró una probabilidad de que un 88,4\% de las TTs no eran costo-efectivas. El impacto de la incorporación de los IPs fue negativo, y el resultado habría sido diferente si se hubiese realizado un análisis previo de coste-efectividad.

Economía; Preparaciones Farmacéuticas;

Toma de Decisiones; Hepatitis C;

Inhibidores de Proteasas
Submitted on 26/Mar/2019

Final version resubmitted on 28/Jun/2019

Approved on 02/Aug/2019 